\title{
Muğla İlinde Yetiștirilen Zeytin (Olea europaea L.) Ağaçlarının Bor ve Makro Elementler Yönünden Beslenme Durumunun Belirlenmesi, Toprak ve Bitki İlișkileri
}

\author{
Aișe Deliboran', Muzaffer Kerem Savran', Özgür Dursun', Önder Eralp', Tülin Pekcan', \\ Hatice Sevim Turan', Erol Aydoğdu', İdris Çılgın', Handan Ataol Ölmez', Șule Savran', \\ Feriște Öztürk Güngör' ${ }^{\prime}$ Ayșen Yılırım', Abdullah Suat Nacar²
}

'Zeytincilik Araștırma Enstitüsü Müdürlüğü, İzmir, Türkiye

${ }^{2}$ GAP Tarımsal Araștırma Enstitüsü Müdürlüğü, Șanlıurfa, Türkiye.

\begin{abstract}
*Sorumlu yazar e-mail (Corresponding author e-mail): aise.deliboran@tarimorman.gov.tr
Geliș tarihi (Received) : 03.03.2020

Kabul tarihi (Accepted): 16.07.2020

DOI: $10.21657 /$ topraksu.690834
\end{abstract}

\section{Öz}

Bu çalıșma, Muğla ilinde zeytin yetiștiriciliği yapılan toprakların ve zeytin bitkisinin bor ve makro elementler yönünden beslenme durumunun belirlenmesi amacıyla yürütülmüștür. Bu amaçla Muğla ili Datça, Köyceğiz, Milas, Ula, Seydikemer ilçelerinden toplam 125 bahçeden toprak ve yaprak örnekleri eș zamanlı olarak alınmıștır. Toprak örneklerinde; tekstür, pH, EC, kireç, organik madde, ekstrakte edilebilir P, K, Ca, Mg, Na; yaprak örneklerinde ise toplam P, K, Ca ve Mg analizleri yapılmıștır. Araștırma alanı topraklarının büyük çoğunluğu kumlu-tın ve killi-tın bünyeye sahiptir, organik madde içeriği düșüktür. Hafif alkalin, nötr ve orta asit özelliğine sahip topraklar tuzsuz sınıfında yer almıștır ve büyük çoğunluğu yüksek kireç içermektedir. Toprak ve yaprak analiz sonuçlarına göre; Araștırma alanı topraklarında B, P, K açısından ciddi beslenme sorunlarının yașandığı tespit edilmiștir. Ca ve Mg bakımından da çok ciddi oranda olmasa da beslenme sorunlarının yașandığı saptanmıștır. Ayrıca toprağın besin maddesi miktarları ile yapraktaki besin maddeleri arasında güvenilir düzeyde korelatif ilișkiler elde edilmiștir. Muğla ilinde gerçekleștirilen bu çalıșmanın sonuçları dikkate alındığında, etkili gübreleme programı, yöntemi ve zamanının son derece önemli olduğu anlașımaktadır. Zeytin tarımında kaliteli ve yüksek verimli üretim; dengeli gübreleme, organik gübre ilavesi ve diğer teknik uygulamalarla ilgilidir.

Anahtar Kelimeler: Zeytin, bor, toprak verimliliği, bitki besleme, Muğla

\section{Determination of Nutritional Status of Olives (Olea europaea L.) Grown in Izmir Province in Terms of Boron and Other Elements}

\section{Abstract}

This study was conducted to determine the nutritional status of olive cultivated land and olive plant in Muğla province in terms of boron and other elements. For this purpose, soil and leaf samples were collected from 125 gardens in Datca, Koycegiz, Milas, Ula, Seydikemer In soil sample were made texture, soil reaction, electrical conductivity, lime, organic matter, extractable boron, phosphorus, potassium,

\footnotetext{
A. Deliboran 0000-0002-0816-9535

K. Savran 0000-0002-9048-4947

Ö. Dursun 0000-0001-6849-3946

Ö. Eralp 0000-0002-3155-2022

T. Pekcan 0000-0002-5534-2548

H. S. Turan 0000-0003-4266-7420

E. Aydoğdu 0000-0001-8682-4227
}

\author{
i. Çılgın 0000-0002-3080-4371 \\ H. A. Ölmez 0000-0003-4577-8804 \\ S. Savran 0000-0001-6105-2407 \\ F. Ö. Güngör 0000-0002-0678-7305 \\ A. Yıldırım 0000-0002-4122-273x \\ A. S. Nacar 0000-0002-8372-7381
}


calcium, magnesium, sodium analysez. In plants samples were determined total boron, phosphorus, potassium, calcium, magnesium. The vast majority of the research area has sandy-tin and clayey-tin structure and low organic matter content. Lightly alkaline, neutral and medium acidic soils are in the salt-free class and contain about high lime. According to soil and leaf analysis results; Although all of the soil contains sufficient boron, the lack of boron in 93\% of the leaves indicates that the plant does not benefit from the existing boron. It was determined that there was serious nutritional problems in terms of $\mathrm{B}, \mathrm{P}, \mathrm{K}$. At the least, there was nutriotinal problems in terms of Ca and $\mathrm{Mg}$. Also, secure correlative relationships between the amounts of nutrient in the soil and the amounts of nutrient in the leaf were obtained. Considering the results of this study conducted in Muğla province, it is understood that effective fertilization program, method and time are extremely important. High quality and high yield production in olive agriculture; balanced fertilization, addition of organic fertilizers and other technical applications

Keywords: Olive, boron, soil fertility, plant nutrition, macro element

\section{Gíriș}

Dünya ham tane zeytin üretimi 2013 yılında 10.2 milyon ha alanda 20.3 milyon ton olarak gerçekleșmiștir. Zeytin üretiminde lider durumda bulunan ülke 7.9 milyon ton üretimiyle İspanya'dır (FAO, 2013). Türkiye Ulusal Zeytin ve Zeytinyağı Konseyi'nin 2014 yılı verilerine göre Türkiye'de 1.4 milyon ton ham tane zeytinden, 439 bin ton sofralık zeytin ve 190 bin ton zeytinyağı elde edilmiștir (UZZK, 2014). Türkiye yıldan yıla değișikler göstermekle birlikte ham tane zeytin ve zeytinyağı üretiminde İspanya, İtalya ve Yunanistan'ın ardından 4. sırada, sofralık zeytin üretiminde ise yine İspanya'nın ardından 2. sırada yer almaktadır (IOC, 2014). Türkiye'de 439.000 ton sofralık, 1.330.000 ton yağlık zeytin üretimi yapılmıș, ortalama verim sofralık zeytinde $10 \mathrm{~kg}$ ağaç-1, yağlık zeytinde ise $14 \mathrm{~kg}$ ağaç-1 olarak gerçekleșmiștir. Türkiye'nin toplam zeytin üretiminin 1.769.000 ton olduğu düșünüldüğünde 940.034 ton üretimiyle Ege Bölgesi'nin \% 53'lük bir paya sahip olduğu, İzmir ve Muğla illerinin Ege Bölgesi zeytin üretimindeki payının ise sırasıyla \% 32 ve \% 19 olarak gerçekleștiği görülmektedir (TUiK, 2014). Türkiye'de üretilen zeytinin yaklașık \% 6570'i zeytinyağı üretiminde kullanılmaktadır.

Zeytin ağacında periyodisiteden dolayı zeytin ve zeytinyağı üretimi yıllara göre inișli çıkıșlı bir grafik izlemekte ve üretime bağlı olarak bir yıl düșük (yok yılı) bir yıl yüksek (var yılı) ürün alınmaktadır. Ayrıca diğer ürünlerde olduğu gibi zeytin ağaçlarının da gübrelendiği ancak bu uygulamalarda bilimsel esaslara uyulmadığı, genelde tek taraflı ve çoğunlukla da yalnızca azotlu gübreleme yapıldığı izlenmektedir. Bu nedenlerle zeytinliklerde verim ortalamamı yağlık çeșitlerde 11 kg daª kadar gerilemiș durumdadır. Dünya ortalamalarının altında olan zeytin verimini artırmak, kaliteyi düzeltmek ve periyodisiteden kaynaklanan üretim dalgalanmalarını azaltmak zeytin tarımımızın esas hedefleridir (Doran ve Aydın, 1999; TUIK, 2011; Deliboran vd., 2019b). Ancak son yıllarda iklim koșullarının düzelmesi, yeni zeytin fidanlarının dikimi ve zeytin üretiminin özendirilmesi konusundaki çalıșmaların da etkisiyle zeytin üretimi artıș göstermiștir. Yine de uygun bakım, hasat ve sulama tekniklerinin tam olarak uygulanamaması gibi sebeplerle var ve yok yılları arasındaki üretim farkı büyük olmaktadır. Zeytin üretimindeki olumlu gelișmelere paralel olarak son yıllarda zeytin sıkma tesislerinin modernleșmesi, kapasitelerinin artması ve modern rafine zeytinyağı ișleme tesislerinin devreye girmesiyle birlikte zeytinyağı üretim miktarı ve kalitesinde de ilerleme kaydedilmiștir (Deliboran vd., 2019a). Türkiye ekonomisi için çok önemli bir bitki olan zeytin, araștırmanın yürütüldüğü ilin çiftçileri ve ekonomisi için daha da önemlidir. Türkiye'de yaklașık 400.000 aile geçimini zeytincilikten sağlamaktadır. Bu bakımdan bölgede yapılacak çalıșmalar ile zeytin verimi ve özellikle de kalitesinin (besin değeri) artırıması ülke ve bölge ekonomisine büyük katkılar sağlayacaktır.

Sofralık zeytin ve zeytinyağının yüksek oranda tüketildiği ülkelerde kalp ve damar rahatsızıkları nedeniyle gerçekleșen ölümlerin daha az rastlandığı bildirilmiștir. Fransa'da yapılan bir araștırmada Akdeniz diyetiyle beslenen insanlarda yașam süresinin ve konforunun daha yüksek olduğu rapor edilmektedir (Tripoli vd., 2005). Sağlık konusundaki olumlu etkisinden dolayı zeytine olan ilgi gittikçe artmaktadır. Bu bağlamda özellikle 
antioksidanlar, lifli besinler ve mikro besin maddeleri bakımından zengin bitkisel gıdaların üretimi önem kazanmaktadır (Deliboran ve Savran, 2017; Deliboran vd., 2019a). Mevcut üretim miktarılya bile zeytin ve zeytinyağının ülke ekonomisine katkısı küçümsenmeyecek düzeydedir. Ancak Türkiye birim alandan elde edilen ürün, kalite ve dıșsatım açısından bazı ülkelerden geridedir. Bu da zeytin ve zeytinyağı üretiminin henüz istenilen düzeye ulașamadığının bir göstergesidir. Yeni tarım alanları açılmasının sınılı olması nedeniyle tarımsal üretimin arttırılmasında en uygun çözüm, birim alandan alınan ürün miktarının arttırıması olarak görülmektedir. Bunun için de verimi artırıcı her türlü teknik ve kültürel bakım ișleri önem kazanmaktadır. Örneğin bitki besleme alanında farklı ülkelerde yapılan çalıșmalardan elde edilen sonuçlar gübre uygulamalarının verim üzerine \% 50 olumlu etkisi olduğunu göstermektedir. Ancak bu uygulamanın bilinçli ve dengeli bir șekilde yapılması gerekmektedir. Dengeli gübreleme, toprak analizine göre toprakta yeterli ve uygun oranlarda bulunmayan bütün besin elementlerinin uygun zamanda, uygun formda, uygun miktarda ve uygun șekilde bitkilere verilmesidir (Deliboran ve Savran, 2017). Dengeli bir gübreleme araștırmanın yürütüleceği bölge topraklarında daha büyük önem tașı-maktadır. Bölgedeki zeytinliklerin genellikle meyilli arazilerde yer alması ve bakım tedbirlerinin tam olarak uygulanmaması gibi nedenlerle beslenme problemlerine sik rastlanmaktadır. Zeytin ağaçları diğer meyve türlerine oranla olumsuz koșullara daha dayanıklı olmakla beraber beslenme yetersizliğinden verim ve kalite düșmesi gibi sorunlar ortaya çıkmaktadır. Nitekim son yıllarda yapılan çalıșmalarda söz konusu bölge topraklarında mikro besin elementleriyle ilgili beslenme problemlerinin yaygınlık gösterdiği ortaya konulmuștur. Türkiye zeytinliklerinin beslenme durumlarını belirleme konusunda yapılan sörvey çalıșmalarında, önem sırasına göre en çok $B, Z n, K$ ve $N$ noksanlıklarının bulunduğu belirlenmiștir (Dikmelik, 1989; Genç vd., 1991; Aksalman vd., 1993; Tekin vd., 1990; Doran ve Aydın, 1999). Mikro besin elementleri bitkiler tarafından çok az miktarlarda alınmasına rağmen bitki metabolizmasında önemli ișlevlere sahiptir. Bu elementlerden biri de bor'dur. Bor, bitkilerin gelișebilmesi için mutlak gerekli olan mikro besin elementlerinden birisidir. Bu nedenle mutlak gerekli mikro besin elementleri arasında bulunan bor, noksanlık ve toksisite belirtileri ile en yaygın olarak görülmektedir. Böyle olunca da borun bitki beslemede ki rolü oldukça dikkat gerektiren bir konum kazanmaktadır (Deliboran vd., 2019a).

Bor hücre bölünmesinde anahtar rol oynamaktadır. Bu nedenle borun meyve gelișiminin ilk haftasında meyve dokusunda yeterince yer alması meyvelerin iri olmasını etkilemektedir (Dugger, 1973). Bor noksanlığı, ürün artıșında iklim koșullarına da bağlı olarak diğer mikro besin maddelerinden daha fazla etki göstermektedir. Bu nedenle ürünün çok olduğu yıl diğer mikro element gübrelemelerinden çok daha önemli bir yere sahiptir (Reisenauer vd., 1973). Zeytin bor eksikliği görülen bitkiler arasında yer almaktadır (Demirtaș, 2005; Deliboran vd., 2019a). Yapılan son araștırmalar borun genaratif organlarda yeterli düzeyde bulunmasının verimlilik açısından gerekli olduğunu ve hatta bor noksanlığı belirtisi görülmeyen meyve ağaçlarında bile dıșsal bor takviyesinin antepfıstığı, badem, zeytin, elma, vișne gibi çeșitli meyve türlerinde verimi arttırdığını göstermektedir (Hanson, 1991a; Nymora vd., 1997; Stover vd., 1999; Perica vd., 2001 b).

Sonuç olarak zeytin/zeytinyağı verim ve kalitesinin artırılması bölge çiftçisi ve sonuçta ülke ekonomisi açısından büyük önem arz etmektedir. Bu da ancak mevcut üretim alanlarının beslenme sorunlarının tespit edilmesi ve elde edilecek sonuçlara göre yapılacak gübreleme çalıșmaları ile mümkün olabilecektir. Bu çalıșma ile Muğla ilindeki zeytin bahçelerinin bor ve makro elementler yönünden beslenme durumunu toprak-yaprak analizleri ile incelemek, elde edilen sonuçları referans değerlerle karșılaștırmak, çeșitli nedenlerle ortaya çıkan sorunları ve toprak bitki ilișkilerini saptamak amaçlanmıștır.

\section{MATERYAL VE YÖNTEM}

Araștırma materyalini olușturan toprak ve yaprak örnekleri Muğla ilinin Datça, Köyceğiz, Milas, Ula, Seydikemer ilçelerinde zeytin üretimi yapılan bahçelerden eș zamanlı olarak alınmıștır. Alınan örnek sayıları ile üretim alanları Çizelge 1'de yer almaktadır.

Örnekleme metodu, örnek alınan yerlerin seçimi ve toprak örneklerinin alınması

Yaprak ve toprak analizlerine dayalı tarama (sörvey) çalıșması gerçekleștirilmiștir. Bu amaçla 125 farklı zeytin bahçesinden toprak ve yaprak örneği eș zamanlı olarak Kasım-Aralık aylarında alınmıștır. 
Çizelge 1. Toprak ve bitki örnekleri sayısı ve ilçelere göre dağılımı Table 1. Number and distribution of soil and plant samples by district

\begin{tabular}{lcccc}
\hline Ilçeler & $\begin{array}{c}\text { Toprak } \\
\text { Örneği } \\
\text { Sayısı } \\
\text { (adet) }\end{array}$ & $\begin{array}{c}\text { Toprak } \\
\text { Dağılımı } \\
(\%)\end{array}$ & $\begin{array}{c}\text { Yaprak } \\
\text { Örneği } \\
\text { Sayısı } \\
\text { (adet) }\end{array}$ & $\begin{array}{c}\text { Yaprak } \\
\text { Dağılımı } \\
(\%)\end{array}$ \\
\hline Datça & 2 & 1.60 & 2 & 1.60 \\
Köyceğiz & 4 & 3.20 & 4 & 3.20 \\
Milas & 80 & 64.00 & 80 & 64.00 \\
Ula & 9 & 7.20 & 9 & 7.20 \\
Seydikemer & 30 & 24.00 & 30 & 24.00 \\
Toplam & 125 & 100.00 & 125 & 100.00 \\
\hline
\end{tabular}

Yaprak örnekleri bahçeyi temsil edecek șekilde farklı ağaçlardan Doğu, Güney, Batı ve Kuzey yönleri olmak üzere ağaçların 4 farklı yönünden, ağaç tacının orta kısmına gelen bir yıllık dallardan karșilıklı yaprak çiftinin alınması șeklinde, toplamda 50 adet olmak üzere sapları ile birlikte koparılarak (Doren ve Aydın, 1999), toprak örnekleri de 0-30 $\mathrm{cm}$ derinliğinden alınmıștır. Örnek alma ișlemi GPS ile koordinatlı olarak gerçekleștirilmiștir.

\section{Alınan örneklerin laboratuvar analizlerine hazırlanması}

Laboratuvara getirilen toprak örnekleri, taș ve bitki parçacıkları ayıklanarak temiz ambalaj kâğıtları üzerine serilerek havada kurumaya bırakılmıștır. Kuruyan topraklar tahta tokmaklarla dövülerek 2 mm'lik çelik elekten geçirilmiș, cam kavanozlara konularak etiketlenmiș ve analize hazır hale getirilmiștir. Laboratuvara getirilen yaprak örnekleri ise önce çeșme suyu, sonra sırası ile $0.1 \mathrm{~N} \mathrm{HCl}$ ve 2 defa deiyonize su ile yıkandıktan sonra fazla suları kurutma kağıdı ile alınarak hava sirkülasyonlu kurutma dolabında $70^{\circ} \mathrm{C}$ de 48 saat (sabit ağırlığa gelinceye kadar) kurutularak ve tungsten kaplı değirmende öğütülerek analize hazır duruma getirilmiștir.

\section{Toprak analiz metotları}

Toprak örneklerinin kum, silt ve kil fraksiyonları hidrometre yöntemine göre, toprak reaksiyonu $(\mathrm{pH})$ saturasyon çamurunda cam elektrotlu $\mathrm{pH}$ metre ile, elektriksel iletkenlik (ECX10 $0^{6}$ mhos $\mathrm{cm}^{-1}$ ) yine saturasyon çamurunda elektriki geçirgenlik aleti ile, kireç $\left(\mathrm{CaCO}_{3} \%\right)$ Scheibler Kalsimetresiyle volümetrik olarak, organik madde (\%) Walkey-Black metoduyla, alınabilir kalsiyum (Ca), magnezyum (Mg), sodyum (Na) ve potasyum (K) $1 \mathrm{~N}$ amonyum asetat $(\mathrm{pH}=7.0)$ ile ekstrakte edilerek süzekteki
Ca, Mg, Na ve K miktarının ICP-OES ile ölçülmesi sonucunda Tüzüner (1990) tarafından bildirildiği șekilde belirlenmiștir. Alınabilir fosfor $(\mathrm{P})$ Olsen (1972)'nin $\mathrm{NaHCO}_{3}$ metoduyla, alınabilir B miktarı ise Gupta (1967) ile Gestring ve Soltanpour (1981) tarafından önerilen sıcak su ekstraksiyon yöntemi ile belirlenmiș ve ölçümler ICP-OES ile yapılmıștır (Kacar, 1982).

\section{Bitki analiz metotları}

Öğütülen bitki kısımlarından $0.3 \mathrm{~g}$ alınıp kapalı sistem mikrodalga cihazında (Cem MarsXpress) $5 \mathrm{ml}$

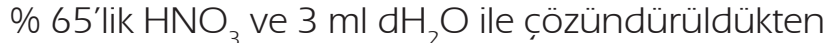
sonra son hacimleri ultra deiyonize su ile 25 ml'ye tamamlanmıș ve mavi bantlı filtre kağıdından süzülmüș, elde edilen süzüklerdeki B ve diğer besin elementlerinin konsantrasyonu ICP-OES (Varian, Vista) ile belirlenmiștir (Zarcinas vd., 1987). Mineral konsantrasyonlarının ölçümleri Ulusal Standartlar ve Teknoloji Enstitüsü (NIST, Gaithersburg, MD, USA)'nden temin edilen referans bitki materyallerindeki ilgili minerallerin sertifikalı değerleri ile kontrol edilmiștir.

\section{BULGULAR VE TARTIȘMA}

\section{Toprakların bazı fiziksel ve kimyasal özellikleri}

Tekstür: Deliboran vd. (2019b)'a göre toprakların kum, kil, silt içerikleri sırasıyla \% 19.5278.40; \% 6.88-58.,88; \% 6.72-49.44 arasında değișmiștir (Çizelge 2). Çizelge 4'de görüldüğü üzere, Anonymus (1951)'e göre toprakların \% 51.16'sı kumlu-tın, \% 17.05'sı killi-tın, \% 15.50'si kumlu-killi-tın, \% 8.53'ü killi, \% 3.88'i tınlı, \% 3.10'u kumlu killi ve geriye kalanı ise tınlı kumlu bünyeye sahiptir (Deliboran vd., 2019b). İyi havalanan, taban suyu düșük, tınlı, killi-tınlı, kumlu-tınlı bünyeli (Kacar ve Katkat, 1999), genellikle \% 34-65 kum, \% 24-28 kil içeren hafif bünyeli toprak (Özbek, 1981; Mengel ve Kirkby, 1987) zeytin gelișimi için uygundur. Zeytin ağacının kumlu-tından killi-tına kadar farklı bünyeye sahip topraklarda yetișebildiği (Çolakoğlu, 1985) ve çalıșmadaki tekstür sınıfları bir bütün olarak dikkate alındığında araștırıcılara göre araștırma alanının büyük çoğunluğunun hafif bünyeli olduğu ve zeytin tarımına uygun oldukları anlașılmıștır (Deliboran vd., 2019b). Zeytinin beslenme durumun saptanması amacıyla yapılan bazı çalıșmalarda toprakların İzmir ilinde killi-tın (Aydoğdu, 2011 ); Gemlik bölgesinde tınlı ve killi-tın (Uysal vd., 2011), Armutlu yarımadasında killi-tın, tınlı ve kumlu (Uysal vd., 2016); Kapıdağ yarımadasında tınlı ve killi-tınlı (Sağlam vd., 2008); 
Çizelge 2. Toprak örneklerinin ekstrakte edilebilir P, K, Ca, Mg ve Na, konsantrasyonları değerleri en düșük, en yüksek ve ortalama değerleri

Table 2. The lowest, highest and average values of the extractable P, K, Ca, Mg ve Na concentration of soil samples

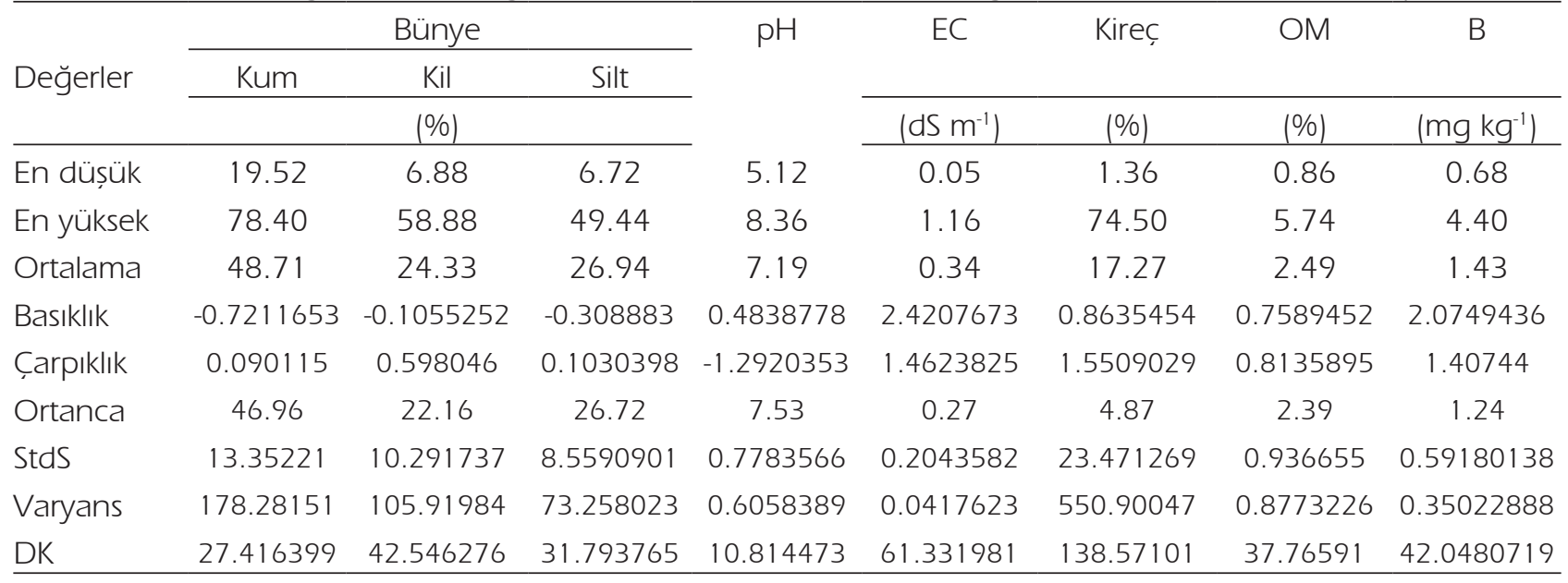

Derik bölgesinde ise tınlı ve killi-tınlı (Doran vd., 2008) bünyeye sahip olduğu belirlenmiștir (Deliboran vd., 2019b).

pH: Deliboran vd. (2019b)'a göre toprakların $\mathrm{pH}$ değeri 5.12 ile 8.36 arasında değișmiștir (Çizelge 2). Toplam alan içinde toprakların \% 50.39'i hafif alkali, \% 22.,83'ü nötr, ve \% 22.44'ü orta asit, \% 3.94'ü alkali karakterdedir (Çizelge 4). Araștırıcılara göre zeytin ağacının geniș bir toprak reaksiyonunda yetișebildiği (Hartmann ve Lilleland, 1966; Özbek, 1981; Llamas, 1984); hafif asidik $(\mathrm{pH}$ 6.5) ve hafif alkali $(\mathrm{pH} 7.8)$ topraklarda iyi gelișim gösterdiği ve araștırma alanı topraklarının \% 50.39'nun hafif alkali ve \% 22.83'nün nötr karakterde olduğu dikkate alındığında bölge topraklarının bu açıdan zeytin tarımına uygun olduğu anlașılmıștır. Araștırıcılar ayrıca alkali reaksiyon gösteren topraklarda $1 \%$ 1.55) pH'yı düșürmek amacıyla kontrollü olarak sonbaharda tercihen çiftlik gübresi ile birlikte toz kükürt uygulanması gerektiğini veya fizyolojik asit karakterli gübrelerin kullanılması gerektiğini vurgulamıșlardır. Zeytinin beslenme durumun saptanması amacıyla yapılan bazı çalıșmalarda toprakların Batı Anadolu Bölgesi'nde nötr ile orta alkali; Gemlik bölgesinde nötr ve hafif alkalin karakterli, (Uysal vd., 2011), Armutlu yarımadasında asit karakterde (Uysal vd., 2016); Kapıdağ yarımadasında büyük çoğunluğunun hafif ve orta asit (Sağlam vd., 2008); İmir (Aydoğdu, 2011), Derik (Doran vd., 2008) ve Urfa (Söylemez vd., 2017) illerinde hafif alkali olduğu belirlenmiștir (Deliboran vd., 2019b).
EC: Deliboran vd. (2019b)'a göre EC değerleri 0.05 ile 1.16 dS m-1 arasında değișmiștir (Çizelge 2). Anonymous (1951)'a göre toprakların \% 100'ü tuzsuz sınıfında yer almıștır (Çizelge 4). Araștırmacılar zeytin ağaçlarının tuza orta derecede mukavim bitkiler (Özbek, 1981; Llamas, 1984) olduğu göz önüne aldıklarında, araștırma alanı topraklarının tuzluluk açısından zeytin yetiștiriciliğine sorun teșkil etmeyeceğini, herhangi bir tuzluluk sorununun șimdilik yașanmadığını ifade etmișlerdir (Deliboran vd., 2019b). Kasırga (2009), Gemlik çeșidi için Na kaynaklı tuzluluk zararının bașladığı noktanın 4.0 dS $\mathrm{m}^{-1}$ ile $8.0 \mathrm{dS}$ $\mathrm{m}^{-1}$ arasında bulunduğunu, $\mathrm{NaCl}$ tuzunun diğer önemli bileșeni olan $\mathrm{Cl}$ elementi ele alındığında ise bitki analiz sonuçları Cl kaynaklı olası tuzluluk zararının bașladığı noktanın köklerde kontrol

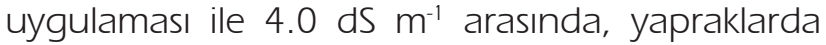

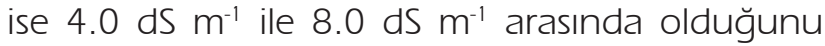
ifade etmektedir. Zeytinin beslenme durumun saptanması amacıyla yapılan bazı çalıșmalarda toprakların tamamının tuzsuz sınıfında yer aldığı (Sağlam vd., 2008; Aydoğdu, 2011; Turan vd., 2013; Söylemez vd., 2017) bildirmișlerdir. Armutlu yarımadasında ise zeytinliklerin \% 96'sı tuzsuz sınıfında (Uysal vd., 2016); Derik bölgesinde ise çoğunlukla az tuzlu (Doran vd., 2008) sınıfında belirlenmiștir (Deliboran vd. 2019b).

Kireç: Deliboran vd. (2019b)'a göre toprakların kireç içerileri \% 1.36 ile \% 74.50 arasında değișmiș (Çizelge 2) ve Evliya (1964)'e göre toprakların \% 34.40' düșük, \% 16.00'i kireçli, \% 16.00'i yüksek, \% 9.60'ı çok yüksek ve \% 24.00'i așırı sınıfında yer almıștır (Çizelge 4). Zeytin genellikle 
yoksul toprakların varsıl bitkisi olarak bilinir, kireçli topraklarda gayet iyi gelișir (Kaçar ve Katkat, 1999). Zeytinin kireç bakımından geniș bir sınıra tolerans gösterdiği ve verimliliğinden bir șey kaybetmediği bilinmektedir (Çolakoğlu, 1985). Bununla beraber en iyi gelișmeyi \% 9-19 oranında yani orta derecede kireç içeren topraklarda gösterir (Hartmann ve Lilleland, 1966; Llamas, 1984; Mengel ve Kirkby, 1987). Araștırıcılara göre çalıșma sonucunda zeytinliklerin \% 34.40'nın düșük kireç içerdiği görülmüștür. Zeytin gerçekte geniș toprak reaksiyonunda yetișebilen, kirece tolerans gösteren ve kuraklığa dayanıklı bir bitki olduğu, kaliteli ve bol ürün için özel șartların karșılanmasını gerektiği (Özbek, 1981; Llamas, 1984), bu nedenle de bölgede kireci düșük alanlarda toprak özelliklerini belirlemek koșuluyla ve kireçleme materyalinin özelliklerini de dikkate alarak, uygun miktarda kireçleme yapılmasının yararlı olacağı ifade edilmiștir. Araștırma alanı topraklarının yaklașık \% 60'ının yüksek kireç içerdiği (Çizelge 4), bu alanlarda kimyasal gübrelemede kireç oranı düșük gübrelerin seçilmesi ve organik gübre uygulamalarına önem verilmesi gerektiği vurgulanmıștır. Zeytinin beslenme durumun saptanması amacıyla yapılan bazı çalıșmalarda Batı Anadolu Bölgesinde toprakların \% 32.84'ü kireç bakımından düșük, \% 29.35'i kireçli, \% 19.90'ı yüksek ve \% 17.91'i de kireç bakımından çok yüksek (Turan vd., 2013); İzmir ilinde \% 50'si kireççe zengin (Aydoğdu, 2011); Kapıdağ yarımadasında büyük çoğunluğunun az kireçli seviyesinde olduğu (Sağlam vd., 2008); Derik bölgesinde ise CaCO3 seviyelerinin \% 5.03-13.41 arasında değișim gösterdiği ve kireççe zengin topraklar sınıfında yer aldığı (Doran vd., 2008) ve Urfa bölgesinde \% 47.06'sının fazla kireçli, \% 32.35'inin ise çok fazla kireçli (Söylemez vd., 2017) olduğu, Armutlu yarımadasında ise zeytinliklerin kireç içermediği (Uysal vd., 2016) belirlenmiștir (Deliboran vd., $2019 \mathrm{~b}$ ).

Organik madde: Deliboran vd. (2019b)'a göre organik madde içerikleri \% 0.86 ile \% 5.74 arasında değișmiș (Çizelge 2) ve Thun vd. (1955)'e göre \% 68.00'ı az humuslu, \% 31.20'si humusça fakir sınıfında yer almıștır (Çizelge 4). Çalıșmaya göre zeytinliklerin organik madde kapsamlarının düșük olduğu, oransal olarak da büyük çoğunluğunun az ve çok az sınıfına girdiği görülmektedir. Zeytinin, iyi havalanan ve yeterli miktarda nem bulunan toprakları sevmesi nedeniyle araștırıcılara göre bu ortamı yaratan ve ticari gübrelerinin etkinlik derecesini yükselten ahır gübresinin topraklara yeterince ve doğru olarak uygulanması gerektiği, toprağın organik ve inorganik gübreleme ile kombine edilerek ideal bir yetișme ortamı olușturulması gerektiği (Özbek, 1981; Cakır ve Cavușoğlu, 1988), toprak organik madde düzeyinin iyileștirilmesi için sürüm tekniklerine, ahır gübresinin yaygın kullanımına ve yeșil gübrelemeye özel önem verilmesi gerektiği vurgulanmıstır. Toprakların organik madde içerikleri Batı Anadolu Bölgesinde \% 26.37'si çok düșük, \% 58.21'i düșük, \% 12.44'ü yeterli ve \% 2.98'i yüksek (Turan vd., 2013); İzmir ili (Aydoğdu, $2011)$ ve Kapıdağ yarımadasında (Sağlam vd., 2008) tamamı düșük; Gemlik bölgesinde \% 22.7'i az ve çok az, \% 47.7'i orta ve \% 29.7'i yüksek ve çok yüksek düzeyde (Uysal vd., 2011 ), Armutlu yarımadasında \% 28.9'u düșük, \% 30.9'u orta ve \% 40.2'i yüksek ve çok yüksek düzeyde (Uysal vd., $2016)$ belirlenmiștir. Derik bölgesinde \% 1.29-1.98 arasında değișim gösterirken (Doran vd., 2008), Șanlıurfa ilinde \% 0.37-2.32 arasında değișmiștir (Söylemez vd., 2017) ve her ikisinde de yetersiz olduğu ifade edilmiștir (Deliboran vd., 2019b).

\section{Eksrakte edilebilir $\mathrm{P}, \mathrm{K}, \mathrm{Ca}, \mathrm{Mg}$ ve $\mathrm{Na}$}

Toprakların ekstrakte edilebilir P içerikleri 0.07 ile 42.56 mg kg-1 arasında değișmiș, Ülgen ve Yurtsever (1974)'e göre \% 12.00'ı çok yüksek, \% 5.60' yüksek, \% 7.20'si orta, \% 16.00'ו az ve \% 59.20'si çok az sınıfinda yer almıștır. Ekstrakte edilebilir K içerikleri 19.93 ile $710.37 \mathrm{mg} \mathrm{kg}^{-1}$ arasında değișmiș ve FAO (1 990)'a göre \% 11 .20'si çok az, \% 27.20'i az, \% 44.00'u orta, \% 16.80'i iyi, \% 0.80'ni fazla sınıfında yer almıștır. Ekstrakte edilebilir Ca içerikleri 392 ile $7013 \mathrm{mg} \mathrm{kg}^{-1}$ arasında değișmiș ve \% 18.40'। az, \% 31.,20'si yeterli, \% 50.40'ı fazla sınıfında yer almıștır. Ekstrakte edilebilir Mg içerikleri 32.18 ile $1069.37 \mathrm{mg} \mathrm{kg}^{-1}$ arasında değișmiș ve \% 7.20'si çok az, \% 36.80'isı az, \% 43.20'si yeterli, \% 12.80'i fazla sınıfinda yer almıștır. Toprakların ekstrakte edilebilir Na içerikleri ise 1.13 ile $200.22 \mathrm{mg} \mathrm{kg}^{-1}$ arasında değișmiș ve Loue (1968)'e göre toprakların \% 100.00'ü çok düșük seviyede yer almıștır (Çizelge 3; 5). Araștırma sonuçları bir bütün olarak değerlendirildiğinde $\mathrm{P}$ ve K bakımından toprakların yaklașı \% 82.40'ı; Ca açısından \% 18.40'ı; Mg açısından \% 44.00'ü beslenme sorunları yașanmaktadır. Zeytinde fosfor gereksinimi azot ve potasyum kadar yüksek olmasa da bu intiyacın gübreleme ile karșılanması 
Çizelge 3. Toprak örneklerinin ekstrakte edilebilir P, K, Ca, Mg ve Na, konsantrasyonları değerleri en düșük, en yüksek ve ortalama değerleri

Table 3. The lowest, highest and average values of extractable $P, K, C a, M g$ and Na concentrations of soil samples

\begin{tabular}{cccccc}
\hline Değerler & $\mathrm{P}$ & $\mathrm{K}$ & $\mathrm{Ca}$ & $\mathrm{Mg}$ & $\mathrm{Na}$ \\
\cline { 2 - 6 } En düșük & 0.07 & 19.93 & 392 & 32.18 & 1.13 \\
\cline { 2 - 6 } En yüksek & 42.56 & 710.37 & 7013 & 1069.37 & 200.22 \\
Ortalama & 7.98 & 176.78 & 3492 & 236.44 & 18.90 \\
Basıklık & 2.02808318 & 2.86223778 & 2.16534471 & 1.94763936 & 0.00821472 \\
Carpıklık & 15.9112 & 1.568 & 1.10064 & 12.48392 & 3488.48 \\
Ortanca & 8.39 & 1.25 & 0.72 & 12.21 & 3523 \\
StdS & 16.7789348 & 1.20540851 & 1.04915768 & 7.91152415 & 1958.7456 \\
Varyans & 281.532654 & 1.45300968 & 1.10073185 & 62.5922143 & 3836684.33 \\
DK & 105.45361 & 76.8755428 & 95.3225109 & 63.3737171 & 56.1489704 \\
\hline
\end{tabular}

önemlidir (Kacar ve Katkat, 1999). Zeytin ağaçları için toprak reaksiyonundan çok toprağın Ca içeriğinin gelișmeye daha etkili olduğu ve değișebilir kalsiyumun $2000 \mathrm{mg} \mathrm{kg}^{-1}$ 'dan, fosforun 20 mg kg1 'dan çok, potasyumun ise $100-120 \mathrm{mg} \mathrm{kg}^{-1}$ olması gerektiği bildirilmektedir (Hartmann ve Lilleland, 1966; Llamas, 1984; Mengel ve Kirkby, 1987; Deliboran vd., 2019b). Bu bağlamda araștırma alanında söz konusu beslenme sorunlarının giderilmesi için $\mathrm{P}, \mathrm{K}, \mathrm{Ca}$ ve $\mathrm{Mg}$ gübrelemesine önem verilmesi gerektiği söylenebilir. Zeytinin beslenme durumun saptanması amacıyla Batı Anadolu Bölgesinde yapıllan bir çalıșmalarda P, K, Ca, Mg içerikleri bakımından toprakların sırasıyla yaklașık \% 84; \% 46; \% 73; \% 87'si yeterli ve yüksek sınıfında belirlenmiștir (Turan vd., 2013). Bir diğer çalıșmada İzmir ilinde Uslu ve Domat zeytin çeșitlerine ait topraklarda P, K, Ca, Mg içeriklerinin sırasıyla $33.37-75.90 \mathrm{mg} \mathrm{kg}^{-1} / 33.71-82.12 \mathrm{mg}$ $\mathrm{kg}^{-1} ; 171.61-316.67 \mathrm{mg} \mathrm{kg}^{-1} / 214.15-471.52 \mathrm{mg}$ $\mathrm{kg}-1$; 2457.75-4453.63 mg kg-1 / 2484.40-5564.6 $\mathrm{mg} \mathrm{kg}^{-1}$ ve 104.39-215.72 $\mathrm{mg} \mathrm{kg}^{-1} / 112.76-268.89$ $\mathrm{mg} \mathrm{kg}^{-1}$ arasında değiștiği $\mathrm{Mg}$ haricinde hepsinin yeterli ve yüksek sınıfında yer aldığı tespit edilmiștir (Aydoğdu, 2011). Derik bölgesinde zeytinliklerin alınabilir P, K, Ca ve Mg içerikleri sırasılyla 13.7-26.6 $\mathrm{mg} \mathrm{kg}^{-1} ; 260-460 \mathrm{mg} \mathrm{kg}^{-1} ; 2200-3000 \mathrm{mg} \mathrm{kg}^{-1}$ ve 695-1223 mg kg-1 arasında değișmiș ve hepsi yeterli sınıfında belirlenmiștir (Doran vd., 2008). Șanlıurfa ilinde ise alınabilir $\mathrm{P}, \mathrm{K}, \mathrm{Ca}$ ve $\mathrm{Mg}$ içerikleri sırasıyla $1.68-22.48 \mathrm{mg} \mathrm{kg}^{-1}$; $228-678 \mathrm{mg} \mathrm{kg}^{-1}$ ve $1242-$ $8516 \mathrm{mg} \mathrm{kg}^{-1} ; 127 \mathrm{mg} \mathrm{kg}^{-1}$ ile $951 \mathrm{mg} \mathrm{kg}^{-1}$ arasında değișmiș, P bakımından yaklașık \% 82.35'i az, Ca ve Mg bakımından ise büyük çoğunluğu yeterli ve fazla sınıfında belirlenmiștir (Söylemez vd., 2017).

\section{Eksrakte edilebilir B}

Deliboran vd. (2019b)'a göre Muğla ilinde zeytin tarımı yapılan bahçelere ait toprakların ekstrakte edilebilir B içerikleri 0.68 ile $4.40 \mathrm{mg} \mathrm{kg}^{-1}$ arasında değișmiștir (Çizelge 2). Araștırmaya göre incelenen toprakların ekstrakte edilebilir B kapsamları Wolf (1971)'a göre değerlendirildiğinde toprakların \% 87.20'si yeterli, \% 12.80'i fazla yer almıștır (Çizelge 4). Toprakların total B kapsamları $20-200 \mathrm{mg} \mathrm{kg}^{-1}$ arasında, alınabilir B fraksiyonu ise $0.4-5 \mathrm{mg} \mathrm{kg}$ 'arasındadır (Gupta, 1979; Deliboran ve Savran, 2017 ). Toprakların sıcak su ile ekstrakte edilebilir bor miktarı $0.5 \mathrm{mg} \mathrm{kg}^{-1}$ 'dan düșük ise bitkiye elverișli bor miktarının yetersiz, $0.5-5 \mathrm{mg} \mathrm{kg}^{-1}$ arasında ise yeterli düzeyde olduğu belirtilmektedir (Sillanpaa, 1982; Deliboran ve Savran, 2017). Araștırma sonuçlarına göre bu bağlamda araștırma alanı topraklarının B içeriği bakımından yeterli olduğu görülmektedir. Zeytinin beslenme durumun saptanması amacıyla yapılan bazı çalıșmalarda toprakların bor içerikleri Batı Anadolu Bölgesinde \% 32.84'ünün düșük, $\%$ 63.18'inin yeterli ve \% 3.98'inin yüksek (Turan vd., 2013); İmir ilinde bor içerikleri 1.47-5.34 $\mathrm{mg} \mathrm{kg}^{-1} ; 1.15-3.87 \mathrm{mg} \mathrm{kg}^{-1}$ arasında değiștiği ve yeterli olduğu (Aydoğdu, 2011 ); Derik bölgesinde zeytinliklerin alınabilir B içerikleri ise $0.37-0.53 \mathrm{mg}$ $\mathrm{kg}^{-1}$ değerleri arasında değiștiği ve yetersiz olduğu (Doran vd., 2008), Șanlıurfa ilinde ise \% 100'ünde yetersiz (Söylemez vd., 2017) olduğu belirlenmiștir (Deliboran vd., 2019b).

\section{Bitki analiz sonuçları}

Toplam P, K, Ca, Mg: Zeytin yapraklarının toplam P, K, Ca ve Mg içerikleri sırasıyla; \% 0.04-0.28; \% $0.40-1.54 ; \% 0.35-2.41 ; \% 0.04-0.31$ arasında 
Çizelge 4. Topraklarının bünye, pH, EC, kireç, OM ve ekstrakte edilebilir B yönünden durumu ve dağılımı (Deliboran vd., 2019)

Table 4. Condition and distribution of soils in terms of texture, $\mathrm{pH}, E C$, lime, $O M$ and extractable $B$

\begin{tabular}{|c|c|c|c|c|}
\hline Besin Elementi & Sınır Değer & Değerlendirme & $\begin{array}{c}\text { Toplam Örnek Sayısı } \\
\text { (adet) }\end{array}$ & Dağılımı (\%) \\
\hline \multirow{7}{*}{$\begin{array}{l}\text { Bünye } \\
\text { (Anonymous, 1951) }\end{array}$} & & Kumlu Tın & 35 & 28.00 \\
\hline & & Tınlı & 33 & 26.40 \\
\hline & & Kımlu Killi Tın & 20 & 16.00 \\
\hline & & Killi & 12 & 9.60 \\
\hline & & Kumlu Killi & 2 & 1.60 \\
\hline & & Killi Tın & 23 & 18.40 \\
\hline & & Tınlı Kumlu & 0 & 0.00 \\
\hline \multirow{6}{*}{$\mathrm{pH}$} & $<5.1$ & Kuvvetli asit & 1 & 0.80 \\
\hline & $5.1-6.6$ & Orta asit & 26 & 20.80 \\
\hline & $6.6-7.3$ & Nötr & 22 & 17.60 \\
\hline & 7.4-7.9 & Hafif alkali & 68 & 54.40 \\
\hline & $7.9-8.5$ & Alkali & 8 & 6.40 \\
\hline & $>8.5$ & Kuvvetli alkali & 0 & 0.00 \\
\hline \multirow{5}{*}{$\begin{array}{l}\mathrm{EC} \\
\left(\mathrm{dS} \mathrm{m}^{-1}\right) \\
\text { (Anonymus, 1951) }\end{array}$} & $<2.5$ & Tuzsuz & 125 & 100.0 \\
\hline & $2.6-4.5$ & Hafif tuzlu & 0 & 0.0 \\
\hline & $4.6-6.9$ & Orta tuzlu & 0 & 0.0 \\
\hline & $7.0-10$ & Yüksek tuzlu & 0 & 0.0 \\
\hline & $>10$ & Așırı tuzlu & 0 & 0.0 \\
\hline \multirow{5}{*}{$\begin{array}{l}\text { Kireç } \\
\text { (\%) } \\
\text { (Evliya, 1964) }\end{array}$} & $<2.5$ & Düșük & 43 & 34.40 \\
\hline & $2.6-5.1$ & Kireçli & 20 & 16.00 \\
\hline & $5.1-10.1$ & Yüksek & 20 & 16.00 \\
\hline & $10.1-20.0$ & Çok yüksek & 12 & 9.60 \\
\hline & $>20.0$ & Așırı & 30 & 24.00 \\
\hline \multirow{3}{*}{$\begin{array}{l}\text { OM (\%) } \\
\text { (Thun vd., 1955) }\end{array}$} & $0-2$ & Humusca fakir & 39 & 31.20 \\
\hline & $2-5$ & Az humuslu & 85 & 68.00 \\
\hline & $>5$ & Humuslu & 1 & 0.80 \\
\hline \multirow{4}{*}{$\begin{array}{l}\mathrm{B} \\
\left(\mathrm{mg} \mathrm{kg}{ }^{-1}\right)\end{array}$} & $<0.5$ & $\mathrm{Az}$ & 0 & 0.00 \\
\hline & $0.5-2.00$ & Yeterli & 109 & 87.20 \\
\hline & $2.00-5.00$ & Fazla & 16 & 12.80 \\
\hline & $>5.00$ & Çok fazla & 0 & 0.00 \\
\hline
\end{tabular}

değișmiștir (Çizelge 7). Reunters ve Robinson (1997)'e göre zeytin yapraklarındaki mineral elementlerin sınır değerleri P için \% 0.10-0.30; K için \% 1.5-2.0; Ca için \% 1.0-1.4; $\mathrm{Mg}$ için ise \% $0.10-0.20$ arasındadır. Jones vd. 1991'e göre ise $\mathrm{P}$ için \% 0.10-0.30; $\mathrm{K}$ için \% 0.90-1 .20; Ca için >\% 1.0; $\mathrm{Mg}$ için ise $>\% 0.20$ yeterli sınır değerleridir. Araștırma alanı yapraklarının P içerikleri bakımından dağılımı \% 13.60'ı az, \% 86.40' ı yeterli; K içerikleri bakımından \% 55.20'si az, \% 40.00'ı yeterli ve \% 4.80'i fazla; Ca içerikleri bakımından \% 25.60' az, \% 38.40' ı yeterli, \% 36.00' fazla; Mg içerikleri bakımından ise \% 20.80'i az, \% 76.80'i yeterli,
\% 2.40'ı fazla seviyededir (Çizelge 8). Toprak örneklerinin \% 75.60'nın çok az ve az seviyede (Çizelge 5) ve yaprak örneklerinin \% 13.60'nın az düzeyde (Çizelge 8) P içerdiği dikkate alındığında P bakımından beslenme sorunun yașandığı görülmektedir. K bakımından toprakların yaklașık \% 82.40'nın çok az, az ve orta düzeyde (Çizelge 5), yaprakların \% 55.20'nin az düzeyde (Çizelge 8) K içerdiği dikkate alındığında araștırma alanının \% 55.20'sinde K bakımından beslenme sorunlarının yașandığı söylenebilir. Toprak örneklerinin \% 18.40'nın (Çizelge 5) ve yaprakların \% 25.60'nın az düzeyde (Çizelge 8) Ca içerdiği düșünüldüğünde 
Çizelge 5. Muğla ili topraklarının ekstrakte edilebilir P, K, Ca, Mg ve Na yönünden durumu ve dağıımı

Table 5. The status and distribution of extractable $P, K, C a, M g$ and Na of soils in Muğla province

\begin{tabular}{|c|c|c|c|c|}
\hline Besin Elementi & $\begin{array}{c}\text { Sınır Değer } \\
\left(\mathrm{mg} \mathrm{kg}^{-1}\right)\end{array}$ & Değerlendirme & $\begin{array}{c}\text { Toplam Örnek } \\
\text { Sayısı (adet) }\end{array}$ & Dağıımı (\%) \\
\hline \multirow{5}{*}{$\begin{array}{c}P \\
\text { (Yurtsever, 1974) }\end{array}$} & $0-5$ & Çok az & 74 & 59.20 \\
\hline & $5-10$ & $\mathrm{Az}$ & 20 & 16.00 \\
\hline & $10-15$ & Orta & 9 & 7.20 \\
\hline & $15-20$ & Yüksek & 7 & 5.60 \\
\hline & $>20$ & Çok yüksek & 15 & 12.00 \\
\hline \multirow{5}{*}{$\begin{array}{c}K \\
(F A O, 1990)\end{array}$} & $<50$ & Çok az & 14 & 11.20 \\
\hline & $50-100$ & $\mathrm{Az}$ & 34 & 27.20 \\
\hline & $100-300$ & Orta & 55 & 44.00 \\
\hline & $300-1000$ & İyi & 21 & 16.80 \\
\hline & $>1000$ & Fazla & 1 & 0.80 \\
\hline \multirow{5}{*}{$\begin{array}{c}\mathrm{Ca} \\
\left(\mathrm{NH}_{4}^{-} \text {-Asetat) }\right.\end{array}$} & $<380$ & Çok az & 0 & 0.00 \\
\hline & $380-1150$ & $\mathrm{Az}$ & 23 & 18.40 \\
\hline & $1150-3500$ & Yeterli & 39 & 31.20 \\
\hline & 3500-10000 & Fazla & 63 & 50.40 \\
\hline & $>10000$ & Çok fazla & 0 & 0.00 \\
\hline \multirow{5}{*}{$\begin{array}{c}\mathrm{Mg} \\
\left(\mathrm{NH}_{4}-\text { Asetat }\right)\end{array}$} & $<50$ & Çok az & 9 & 7.20 \\
\hline & $50-160$ & $\mathrm{Az}$ & 46 & 36.80 \\
\hline & $160-480$ & Yeterli & 54 & 43.20 \\
\hline & $480-1500$ & Fazla & 16 & 12.80 \\
\hline & $>1500$ & Çok fazla & 0 & 0.00 \\
\hline \multirow{5}{*}{$\begin{array}{c}\text { Na } \\
\text { (Loue, 1968) }\end{array}$} & $<34$ & Çok Düșük & 125 & 100.00 \\
\hline & $34-68$ & Düșük & 0 & 0.00 \\
\hline & $68-230$ & Orta & 0 & 0.00 \\
\hline & $230-460$ & Yüksek & 0 & 0.00 \\
\hline & $>460$ & Çok Yüksek & 0 & 0.00 \\
\hline
\end{tabular}

bahçelerin yaklașık \% 26.00'sında Ca beslenme sorunlarının yașandığı; $\mathrm{Mg}$ bakımından ise toprakların \% 44.00'nün çok az ve az (Çizelge 5), yaprakların ise \% 20.80'nin az düzeyde (Çizelge 8) Mg içerdiği ve söz konusu alanlarda Mg beslenme sorunun yașandığı anlașılmaktadır.

B: Deliboran vd., (2019b)'a göre zeytin yapraklarının toplam B içerikleri 8.66-24.23 $\mathrm{mg} \mathrm{kg}^{-1}$ arasında değișmiș (Çizelge 6) ve zeytin yapraklarının bor içerikleri bakımından dağıımı \% 92.80'i az,
\% 7.20'si yeterli düzeyde saptanmıștır (Çizelge 6). Reunters ve Robinson (1997)'e göre zeytin yapraklarındaki B sınır değerleri 20-150 mg kg-1, Jones vd. (1991)'e göre de $20-75 \mathrm{mg} \mathrm{kg}^{-1}$ arasında değișmektedir. Araștırıcılara göre araștırma alanı toprakların \% 100.00'nün yeterli ve fazla seviyede bor içerdiği (Çizelge 4) ve yaprakların \% 92.80'sinin az düzeyde B içerdiği (Çizelge 8) dikkate alındığında Muğla ilinde zeytin yetiștirilen alanların yaklașı \% 93'ünde ciddi bor beslenme sorunlarının yașandığı

Çizelge 6. Yaprak örneklerinin en düșük, en yüksek, ortalama toplam B konsantrasyonları ve dağılımı (Deliboran vd., 2019) Table 6. The lowest, highest, and average B concentrations of leaf samples

\begin{tabular}{cccccc}
\multicolumn{2}{c}{ B $\left(\mathrm{mg} \mathrm{kg}^{-1}\right)$} & Sınır Değer & Değerlendirme & $\begin{array}{c}\text { Toplam Örnek } \\
\text { Sayısı (adet) }\end{array}$ & $\begin{array}{c}\text { Dağılımı } \\
(\%)\end{array}$ \\
En düșük & 8.66 & $<20$ & Az & 116 & 92.80 \\
En Yüksek & 24.23 & $20-150$ & Yeterli & 9 & 7.20 \\
Ortalama & 15.60 & $150<$ & Fazla & 0 & 0.00 \\
\hline
\end{tabular}


Çizelge 7. Yaprak örneklerinin toplam P, K, Ca ve Mg konsantrasyonları değerleri en düșük, en yüksek ve ortalama değerleri

Table 7. The lowest, highest and average values of total $P, K$, Ca and $\mathrm{Mg}$ concentrations of leaf samples

\begin{tabular}{ccccc}
\hline \multirow{2}{*}{ Değerler } & $\mathrm{P}$ & $\mathrm{K}$ & $\mathrm{Ca}$ & $\mathrm{Mg}$ \\
\cline { 2 - 5 } & \multicolumn{4}{c}{$(\%)$} \\
\hline En düșük & 0.04 & 0.40 & 0.35 & 0.04 \\
En yüksek & 0.28 & 1.54 & 2.41 & 0.31 \\
Ortalama & 0.13 & 0.80 & 1.23 & 0.13 \\
\hline
\end{tabular}

anlașılmaktadır (Çizelge 7). Toprakların yaklașık tamamındayeterli bor olmasına rağmen yaprakların \% 93'ünde bor noksanlığının görülmesinin toprakta var olan bordan bitkinin faydalanmadığını gösterdiği, ülkemiz zeytinliklerinin beslenme durumlarını belirleme konusunda yapılan sörvey çalıșmalarında, önem sırasına göre en çok $B, Z n, K$, ve $\mathrm{N}$ noksanlıklarının bulunduğu vurgulanmıștırir (Canözer, 1978; Dikmelik, 1984; Genç vd., 1991; Aksalman vd., 1993; Tekin vd., 1994; Doran ve Aydın, 1999; Deliboran vd., $2019 b$ ). Özbek (1981), bor noksanlığı görülen meyve ağaçlarına, bu elementin noksanlık sınırı ile zehir etkisi gösterdiği sınırın birbirine çok yakın olması sebebiyle topraktan uygulanmasının sakıncalı olabileceğini, bu nedenle borun yapraktan püskürtülerek verilmesi ile meyve ve yapraklarda istenilen bor düzeylerinin daha kolay sağlanabileceğini bildirmiștir. Boraks veya borik asit çözeltisi halinde yapraklara \% 0.15-0.24' lük konsantrasyonlarda püskürtülmesiyle birçok meyve türünde ortaya çıan bor noksanlığının giderilebileceğini bildirmiștir. Perica vd. (2001a), çalıșmada verim çağındaki Manzanillo zeytin çeșidinin değișik organlarındaki bor hareketi, manitol ve glukoz konsantrasyonları ve B uygulamasının çözünebilir karbonhidratlar üzerindeki değișim etkilerini etiketli B kullanarak incelemișlerdir. 10B uygulaması ile muamele edilmiș çeșitli yașlardaki yapraklardan uygulamayı takiben önemli oranda 10B çıkıșı olduğunu ve çiçek salkımları ile meyvelerinde içinde bulunduğu uygulama yapılmayan komșu organlarda önemli oranda 10B artıșının gerçekleștiğini bildirmișlerdir. Sonuçlar, B' un değișik yaștaki yapraklardan tașınabildiğini ve zeytinde yapraktan uygulanan B'un floem içerisinde tașınabilir olduğunu ispatlamıștır. Çözünebilir karbonhidrat analizi, analiz edilen tüm organlarda manitol ve glikozun baskın șekerler olduğunu ve yapraklardaki mannitol konsantrasyonunun tüm B tașınımını hesaplamak için yeterli olduğunu saptamıștır.

\section{Toprak ve yaprak besin elementleri arasındaki ilișkiler}

Çizelge 9'da görüldüğü gibi toprağın organik madde içeriği ile toprağın bor içeriği arasında pozitif bir ilișki belirlenmiștir. Topraklarda bitkiye yarayıșlı borun önemli bir kısmı organik maddeye bağlanmıș durumdadır, organik madde içerikleri yüksek toprakların genellikle bor içerikleri de yüksektir (Deliboran ve Savran, 2017). Organik madde içeriği ile sırasıyla toprak pH'sı ve sodyum içeriği arasında 0.01 önem seviyesinde negatif ilișki belirlenmiștir. Toprağın kireç içeriği ile pH; kireç içeriği ile EC; kireç içeriği ile toprağın kalsiyum içeriği; toprağın EC değeri ile toprağın kalsiyum içeriği arasında pozitif ilișki belirlenmiștir. Toprağın EC düzeyi ile toprağın bor, magnezyum, sodyum ve potasyum içeriği arasında 0.01 önem düzeyinde, fosfor içeriği ile ise 0.05 önem seviyesinde pozitif ilișki gözlenmiștir. EC ve $\mathrm{pH}$ değerlerinin topraktaki kalsiyum miktarını etkilediği, kireçli toprakların pH değerlerinin yüksek olduğu bilinmektedir (Aktaș, 1979; 1995). Ayrıca kurak bölgelerde tuzlu topraklarda \% 5'in üzerinde Ca bulunmaktadır (Aktaș, 1995). Toprağın kalsiyum içeriği ile toprağın potasyum içeriği arasında pozitif ilișki belirlenmiștir. Jacabson vd. (1960) arpa bitkisinde düșük pH'da kalsiyumun potasyum alımını arttırdığını bildirmiștir. Toprağın kalsiyum içeriği ile toprağın bor içeriği, toprağın magnezyum içeriği ile toprağın bor ve magnezyum içeriği arasında da

Çizelge 8. Yaprak örneklerinin toplam P, K, Ca ve Mg bakımından durumu ve dağılımı

Table 8. Total amount and distribution of $P, K, C a$ and $M g$ of leaf samples

\begin{tabular}{cccc}
\hline Besin & Sınır & Toplam & \\
Elementi & Değer & Değerlendirme & $\begin{array}{c}\text { Örnek } \\
\text { Sağısımı }\end{array}$ \\
& & $\begin{array}{c}\text { Sayı) } \\
\text { (adet) }\end{array}$ & \\
\hline
\end{tabular}

\begin{tabular}{ccccc}
$P$ & $<0.10$ & Az & 17 & 13.60 \\
$(\%)$ & $0.10-0.30$ & Yeterli & 108 & 86.40 \\
& $0.30<$ & Fazla & 0 & 0.00 \\
\hline \multirow{2}{*}{$\begin{array}{ccc}\text { K } \\
(\%)\end{array}$} & $0.8-1.2$ & Yeterli & 50 & 40.00 \\
& $1.2<$ & Fazla & 6 & 4.80 \\
\hline \multirow{2}{*}{$\mathrm{CA}$} & $<1.00$ & Az & 32 & 25.60 \\
$(\%)$ & $1.00-1.40$ & Yeterli & 48 & 38.40 \\
& $1.40<$ & Fazla & 45 & 36.00 \\
\hline \multirow{2}{*}{$\mathrm{Mg}$} & $<0.10$ & Az & 26 & 20.80 \\
$(\%)$ & $0.10-0.20$ & Yeterli & 96 & 76.80 \\
& $0.20<$ & Fazla & 3 & 2.40 \\
\hline
\end{tabular}


Çizelge 9. Toprak ve yaprak bor ve makro element içerikleri arasındaki ilișkiler

Table 9. Relationships between soil and leaf boron and macro element contents

\begin{tabular}{|c|c|c|c|c|c|}
\hline \multicolumn{2}{|c|}{ İlișkiler } & \multirow{2}{*}{$\frac{r}{0.456^{* *}}$} & \multicolumn{2}{|c|}{ İlișkiler } & \multirow{2}{*}{$\frac{r}{0.4603^{* *}}$} \\
\hline $\mathrm{pH}$ & Top. Ca & & \multirow{3}{*}{ Top. K } & Top. Mg & \\
\hline \multirow{6}{*}{ EC } & Тор. В & $0.3103^{* *}$ & & Top. Na & 0.1901 * \\
\hline & Top. Ca & $0.6065^{* *}$ & & Top. P & 0.2464 ** \\
\hline & Top. Mg & $0.3305^{* *}$ & Yap. P & Yap. B & $0.1739 * *$ \\
\hline & Top. Na & $0.2712 * *$ & \multirow{2}{*}{ Yaр. K } & Yар. B & $0.3167 * *$ \\
\hline & Top. P & $0.1541 *$ & & Yaр. P & $-0.072 *$ \\
\hline & Top. K & $0.6466 * *$ & \multirow{2}{*}{ Yap. Сa } & Yap. B & $0.5954^{*}$ \\
\hline \multirow{3}{*}{ Kireç } & Top. Ca & $0.5732 * *$ & & Yар. P & $0.2206^{* *}$ \\
\hline & $\mathrm{pH}$ & $0.3655^{* *}$ & \multirow{3}{*}{ Үар. Mg } & Yар. В & $0.2078 *$ \\
\hline & $\mathrm{EC}$ & $0.357 * *$ & & Yap. P & $-0.0069 * *$ \\
\hline \multirow{3}{*}{ OM } & Top. B & $0.4054 * *$ & & Yap. Ca & $0.0722^{* *}$ \\
\hline & Top. Na & $-0.301 * *$ & \multirow{3}{*}{ Yaр. P } & Top. B & $0.0715^{* *}$ \\
\hline & $\mathrm{pH}$ & $-0.2763 * *$ & & $\mathrm{pH}$ & $-0.351 * *$ \\
\hline Top. Ca & Top. B & $0.3243 * *$ & & OM & $0.2716^{* *}$ \\
\hline \multirow[t]{2}{*}{ Top. Mg } & Тор. В & $0.2451 * *$ & \multirow{6}{*}{ Yap. Ca } & Top. B & -0.0426 ** \\
\hline & Top. Ca & $0.2557 * *$ & & Top. Ca & 0.0506 * \\
\hline \multirow{3}{*}{ Top. Na } & Top. B & $0.0708 * *$ & & Top. Mg & $0.0567 * *$ \\
\hline & Top. Сa & $0.3558 * *$ & & $\mathrm{pH}$ & $-0.0502^{* *}$ \\
\hline & Top. Mg & $0.2731 * *$ & & Kireç & $0.0729 * *$ \\
\hline Top. P & Top. B & $0.229 * *$ & & OM & $-0.0611 * *$ \\
\hline \multirow{2}{*}{ Top. K } & Top. B & $0.5292 * *$ & \multirow{2}{*}{ Yap. Mg } & Top.B & $-0.2072^{* *}$ \\
\hline & Top. Сa & $0.6094^{* *}$ & & Top. K & $-0.0532^{* *}$ \\
\hline
\end{tabular}

${ }^{*} p<0.05,{ }^{* *} p<0.01$

0.01 önem düzeyinde pozitif ilișki saptanmıștır. Yine toprağın sodyum içeriği ile toprağın sırasıyla bor, kalsiyum ve magnezyum içeriği arasında; toprağın fosfor içeriği ile toprağın bor içeriği arasında 0.01 önem seviyesinde pozitif ilișki belirlenmiștir. Çizelge 8'de görüldüğü gibi toprağın potasyum içeriği ile toprağın sırasıyla bor, kalsiyum, magnezyum ve fosfor içeriği arasında 0.01 önem seviyesinde, sodyum içeriği arasında ise 0.05 önem seviyesinde ilișki gözlenmiștir.

Yaprağın fosfor içeriği ile toprağın pH değeri arasında negatif, toprağın OM ile bor içeriği arasında ise pozitif bir ilișki saptanmıștır. Turan vd. (2013) zeytinde; Hendrix (1967) fasulye bitkisinde yaptığı çalıșmada da negatif ilișki saptamıștır. Yaprağın magnezyum içeriği ile toprağın potasyum ve bor içeriği arasında 0.01 önem seviyesinde negatif bir ilișki belirlenmiștir. Turan vd. (2013) Muğla ilindeki zeytin bahçelerine ait örneklerde, Schimansky (1981) arpa bitkisinde yaptığı çalıșmada negatif ilișki belirlediklerini bildirmiștir. Așırı K gübrelemesi bitki yapraklarında $\mathrm{Mg}$ noksanlığına neden olmaktadır (Aktaș, 1995; Turan vd., 2013; Kacar ve Katkat, 2007). Yaprağın kalsiyum içeriği ile sırasıyla toprağın magnezyum, kireç ve kalsiyum içeriği arasında pozitif ilișki, toprağın bor, pH ve OM içeriği arasında ise negatif bir ilișki belirlenmiștir. Turan vd. (2013) Bursa ve Çanakkale illeri zeytinliklerinde; Scharrer ve Jung (1955) ise ayçiçeğinde negatif ilișki belirlediklerini bildirmișlerdir.

Ayrıca Çizelge 9'da görüldüğü gibi yaprağın fosfor içeriği ile yaprağın bor içeriği, potasyum içeriği ile bor içeriği, kalsiyum içeriği ile bor ve fosfor içeriği, magnezyum içeriği ile bor ve kalsiyum içeriği arasında pozitif ilișki belirlenirken, yaprağın potasyum içeriği ile fosfor içeriği arasında ve yaprağın magnezyum içeriği ile fosfor içeriği arasında negatif ilișki belirlenmiștir.

\section{SONUÇLAR}

Muğla ilinde zeytin tarımı yapılan alanların bor beslenme durumu ve toprakların bazı 
Özellikleri incelenmiș, elde edilen sonuçların zeytin tarımına olan etkileri değerlendirilmeye alınmıștır. Araștırmanın sonuçlarına göre; araștırma alanı topraklarının büyük çoğunluğu kumlu-tın ve killi-tın bünyeye sahiptir, organik madde içeriği düșüktür. Hafif alkalin, nötr ve orta asit özelliğine sahip topraklar tuzsuz sınıfında yer almıștır. Zeytin ağacının geniș bir toprak reaksiyonunda yetișebildiği, hafif asidik ve hafif alkali topraklarda iyi gelișim gösterdiği dikkate alındığında bölge topraklarının bu açıdan zeytin tarımına uygun olduğu görülmektedir. Araștırma alanı topraklarının büyük çoğunluğu yüksek kireç içerdiğinden kimyasal gübrelemede özellikle kireç oranı düșük gübrelerin seçilmesine özen gösterilmelidir. Zeytinin, iyi havalanan ve yeterli miktarda nem bulunan toprakları sevdiği dikkate alındığında bu ortamı yaratan ve ticari gübrelerinin etkinlik derecesini yükselten ahır gübresi topraklara yeterince ve doğru olarak uygulanmalı, ayrıca, toprak organik ve inorganik gübreleme ile kombine edilerek ideal bir yetișme ortamı olușturulmalı, toprak organik madde düzeyinin iyileștirilmesi için sürüm tekniklerine, ahır gübresinin yaygın kullanımına ve yeșil gübrelemeye özel önem verilmelidir. Araștırma sonuçları fosfor, potasyum, kalsiyum ve magnezyum bakımından bir bütün olarak değerlendirildiğinde sırasıyla toprakların yaklașık \% 82.40'ı; \% 82.40'ı; \% 18.40' ve \% 44.00'ında beslenme sorunları yașandığı dikkati çekmektedir. Zeytinde fosfor gereksinimi azot ve potasyum kadar yüksek olmasa da bu ihtiyacın gübreleme ile karșılanması önemlidir. Zeytin ağaçları için toprak reaksiyonundan çok toprağın Ca içeriğinin gelișmeye daha etkili olduğu ve değișebilir kalsiyumun 2000 mg kg-1'dan, fosforun 20 mg $\mathrm{kg}^{-1}$ 'dan çok, potasyumun ise 100-120 mg kg-1 olması gerektiği bilinmektedir. Bu bağlamda araștırma alanında söz konusu beslenme sorunlarının giderilmesi için fosfor, potasyum, kalsiyum ve magnezyum gübrelemesine önem verilmesi gerektiği söylenebilir. Araștırma sonuçları bor, bakımından değerlendirildiğinde B ciddi beslenme sorunlarının yașandığı dikkati çekmektedir. Toprakların tamamının yeterli bor içermesine rağmen yaprakların yaklașık \% 93'ünde bor noksanlığının görülmesi toprakta var olan bordan bitkinin faydalanmadığını göstermektedir. Bu bağlamda araștırma alanında söz konusu beslenme sorunlarının giderilmesi için özellikle bor gübrelemesine önem verilmesi gerekmektedir. Bor noksanlığı görülen meyve ağaçlarına, bu elementin noksanlık sınırı ile zehir etkisi gösterdiği sınırın birbirine çok yakın olması sebebiyle topraktan uygulamanın hassasiyetle yapılması gerektiği, zeytinde yapraktan uygulanan borun floem içerisinde kolaylıkla tașınabilmesi nedeniyle borun yapraktan püskürtülerek verilmesi ile meyve ve yapraklarda istenilen bor düzeylerinin daha kolay sağlanabileceğini düșünülmektedir. Muğla ilinde gerçekleștirilen bu çalıșmanın sonuçları dikkate alındığında, etkili gübreleme programı, yöntemi ve zamanının son derece önemli olduğu anlașılmaktadır. Zeytin tarımında kaliteli ve yüksek verimli üretimin dengeli gübreleme, organik gübre ilavesi ve diğer teknik uygulamaların titizlikle yapılması ile mümkün olabileceği düșünülmektedir.

\section{KAYNAKLAR}

Aktaș M (1979). Doğu Karadeniz topraklarının potasyum durumu ve bu topraklardan alınabilir potasyum miktarının tayininde kullanılacak metodlar üzerine bir araștırma. Ankara Üniversitesi Ziraat Fakültesi Yayınları, 727

Aktaș M (1995). Bitki besleme ve toprak verimliliği, Ankara Üniversitesi Ziraat Fakültesi, Yayın No:1429, Ders Kitabı: 416.

Aksalman A, Dikmelik Ü, Püskülcü G, Özgen N (1993) Aydın yöresi zeytinlerinin beslenme durumunun tespiti (Sonuç Raporu). Zeytincilik Araștırma İstasyonu, İzmir

Anonymous, Soil Survey Staff (1951). Soil Survey Manuel, Agricultural Research Administration, Department of Agriculture Handbook, No:18, Gount Point Office Washington, USA, 340-377.

Aydoğdu E (2011). Domat ve Uslu zeytin çeșitlerinde yaprakların besin element içerikleri ve bunların mevsimsel değișimlerinin incelenmesi. Yüksek lisans tezi, Cukurova Üniversitesi Fen Bilimleri Enstitüsü Toprak Bilimi ve Bitki Besleme Anabilim Dalı, Adana.

Canözer Ö (1978). Ege Bölgesi önemli zeytin çeșitlerinin besin element statüleri ve toprak-bitki ilișkileri. (Uzmanlık Tezi), Zeytincilik Araștırma Enstitüsü, Bornova, İzmir

Çakır M, Çavușoğlu A (1988). Modern zeytincilik (Çeviri) T.O.K.B. Yayın No: 1, Ankara.

Çolakoğlu H (1 985). Gübre ve gübreleme. Ege Üniv. Zir. Fak. Teksir, 17: 1. Bornova, İzmir.

Deliboran A, Savran Ș (2017). Bor, bitki fizyolojisindeki önemi ve meyve ağaçlarında kullanımı. 5. Uluslararası Katılımlı Toprak ve Su Kaynakları Kongresi, Kırklareli, Türkiye.

Deliboran A, Savran K, Dursun O, Eralp O, Pekcan T, Turan HS, Aydogdu E, Cilgin I, Ata Olmez H, Savran S, Ozturk Gungor F, Yildirim A, Nacar AS (2019a). Determination of Nutritional Status in Terms of Boron and the Other Elements of Olives (Olea europaea L.) Grown in Izmir Province. International Semposium on Boron, 17-19 April, Nevsehir Turkey. 
Deliboran A, Savran K, Dursun Ö, Eralp Ö, Pekcan T, Turan HS, Aydoğdu E, Çılgın I, Ata Ölmez H, Savran S, Nacar AS (2019b). Muğla ilinde yetiștirilen zeytin (Olea europaea L.) ağaçlarının bor ve mikro elementler yönünden beslenme durumunun belirlenmesi, yaprak ve toprak ilișkileri. UAZIMDER Uluslararası Anadolu Ziraat Mühendisliği Bilimleri Dergisi, 2019 (Özel Sayı 1): 126-140, ISSN: 26677571.

Demirtaș A (2005). Bitkide bor ve etkileri. Atatürk Üniv. Ziraat Fak. Derg. 36 (2): 217-225, ISSN: 1300-9036.

Dikmelik Ü (1984). Farklı yașlardaki memecik zeytin ağaçlarında dane ve budama artıkları ile topraktan kaldırılan azot, fosfor, potasyum miktarlarının saptanması konusunda bir araștırma. Zeytincilik Araștırma Enstitüsü, Yayın No:31, Bornova, İzmir.

Doran I, Koca YK, Pekkolay B, Mungan M (2008). Derik yöresi zeytinliklerinin beslenme durumunun tespiti. Akdeniz Üniversitesi Ziraat Fakültesi Dergisi, 21 (1): 131-138.

Doran I, Aydın R (1999). İçel yöresi zeytinliklerinin beslenme durumunun tespiti. Anadolu, J. of AARI, 9 (1): 105-130.

Dugger WM (1973). Functional aspects of boron in plants. Advanced Chemistry, 123: 112-129.

Evliya H (1964). Kültür bitkilerinin beslenmesi. A.Ü. Zir. Fak. Yayınları. Sayı 36.

FAO (2013). http://faostat.fao.org/erișim tarihi: 29.03.2015.

FAO (1990). Micronutrient, Assessment at the Country Level:An International Study. FAO Soil Bulletin by Sillanpaa. Rome.

Genç C,. Moltay I, Soyergin S, Fidan AE, Sütçü A (1991). Marmara bölgesi sofralık zeytinlerinin beslenme durumu. Bahçe, Yalova, 20: 1-2.

Gestring WD, Soltanpour PN (1981). Evaluation of wet and dry digestion methods for boron determination in plant samples by ICP-AES. Commun. Soil Sci. Plant Anal., 12: 743753.

Gupta UC (1979). Boron nutrition of crops, Adv. Agronomy, 31: 2373-307.

Gupta UC, Jame YW, Camphell CA, Leyshon A, Misholaıchuk W (1985). Boron toxicity and deficiency, a review can. Journal of Soil Science., 65: 381-409.

Gupta UC (1967). A simplified method for determining hot water-soluble boron in soils. Soil Science, 103: 424-428.

Hanson (1991a). Sour cherry respond to foliar leaves. HortScience, 26 (9): $1142-1145$.

Hartmann HT, Lilleland O (1966). Olive nutrition temperate to tropical fruit nutrition (Ed: N. F. Childers) Hort. Pub. Rutgers, Chapter X. The State Uni. New Jersey.

Hendrix, JE (1967). The effect of $\mathrm{pH}$ on the uptake and accumulation of phosphate and sulphate ions by bean plants. American Journal of Botany, 54: 560.

IOC (2014). http://www. internationaloliveoil.org.

Jacabson L, Moore DP, Hannapel RJ (1960). Role of calcium in absorption of monovalent cations. Plant Physiology, 35: 352-358.
Jones JR, Wolf B, Mills HA (1991). Plant analysis handbook: A practical sampling, preparation, analysis, and interpretation Guide. Micro-Macro Publishing, Athens, GA. Micro-Macro Publishing.

Kacar B (1982). Gübreler ve gübreleme tekniği. T.C. Ziraat Bankası Kültür Yayınları. Ankara.

Kacar B, Katkat AV (1999). Gübreler ve gübreleme tekniği. Uludağ Üniversitesi Güçlendirme Vakfı Yayın No. 144, VIPAȘ Y. No: 20.

Kacar B, Katkat AV (2007). Bitki besleme. Nobel Yayın No: 849, Nobel Basımevi, Ankara, Türkiye, 302.

Kasırga E (2009). Tuzluluğun Gemlik zeytin (Olea europaea L.) çeșidine etkilerinin incelenmesi. Adnan Menderes Üniversitesi Fen Bilimleri Enstitüsü. ZTOYL-2009-0003.

Lindsay WL, Norwell WA (1978). Development of a DTPA soil test for zinc, Iron, manganese and copper. Soil Science Society of America Journal, 42: 421-428.

Llamas JF (1984). Basis of fertilization in olive cultuvation and the olive trees vegetative cycle and nutritional needs. International Course on Fertilization and Intensitication of Olive Cultivation. UNDP-FAO, Cordoba-Spain.

Loue A (1968). Diagnostic pétiolairem de prospection. etudes sur la nutrition etla fertilisation potassiques de la vigne. Sociéte Commerciale des Potasses d' Alsace Services Agronomiques, pp. 31-41.

Mengel K, Kırkby A (1987). Principles of plant nutrition. I.P.I. CH. 3048. Worblaufen-Bern.

Nyomura AMS, Brown PH, Freeman M (1997). Fall foliar-applied boron increase tissue boron concentration and nut set of almond Journal of the American Society for Horticultural Science ISSN0003-1062 Vol. No v. 122 (3): 405-410.

Olsen (1972). Micronutrient Interactions. Micronutrients in Agriculture.Soil Scienne Society of Amerika, İne Madison, Wisconsin USA, pp. 243-264.

Özbek N (1981). Meyve ağaçlarının gübrelenmesi. T.O.K.B. Ankara. p.280.

Perica S, Bellaloui N, Greve C, Hu H, Brown PH (2001a). Boron transport and soluble carbonhydrate concentrations in olive. J.Amer. Soc.Sci. 126 (3): 291-296.

Perica S, Brown PH, Connell JH, Nyomora AMS, Dordas C, Hu H (2001b) Foliar boron application improves flower fertility and fruit set in olive. HortScience 36 (4): 714-716.

Reisenauer HM, Walsh LM, Hoeft RG (1973). Testing soils for sulphur, boron, molybdenum and chlorine, In: LM Walsh and JD Beaton: Soil. pp. 173-200.

Reuter DJ, Robinson JB (1997). Plant analysis and interpretation manual. CSIRO Publishing. ISBN: 643059385 , Collingwood, VIC, Australia.

Sağlam MT, Bellitürk K, Hazinedar N, Danıșman F (2008). Kapıdağ yarımadası zeytinliklerinin beslenme durumu. Selçuk Üniversitesi, Ziraat Fakültesi Dergisi, ISSN: 1300577422, (44): 118-123.

Scharrer K, Jung J (1955). The influence of nutrition on the cation/anion ratio in plants. Z. Pflanzenernahr. Dung. Bodenk. 7: 76-94. 
Schimansky C (1981). Der einflusseiniger versuchsparameter auf das fluxverhalten von $28 \mathrm{Mg}$ bei gerstenkeimpflanzen in hydrokulturversuchen. Landwirtsch. Forsch. 34: 154-165.

Sillanpaa M (1982). Micronutrients and the nutrient status of soils. A Global Study. FAO Soils Bulletin No:48, Rome.

Stover E, Fargione M, Risio R (1999). Problem foliar boron, zinc and urea applications enhance cropping of some "Empire and Mcintosh" apple orchards in New York. HortScience, ISSN: 192-6, Volume: 34 (2): 210-214.

Söylemez S, Öktem G, Kara H, Almaca ND, Ak BE, Sahar E (2017). Sanlıurfa yöresi zeytinliklerinin beslenme durumunun belirlenmesi. Harran Tarım ve Çevre Bilimleri Dergisi, 21(1): $1-5$.

Tekin H, Çağlar G, Kuru C, Akkök F (1990). Antepfistığ besin kapsamlarının belirlenmesi ve en uygun yaprak örneği alım zamanının tespiti. Türkiye 1. Antepfıstığı Sempozyumu Bildiriler. 11-12 Eylül, pp. 120-138.

Thun R, Hermann R, Knickman E (1955). Die Untersuchung Von Boden Neuman Verlag, Radelbeul und Berlin, pp. 48-48.

Tripoli E, Giammanco M, Tabacchi G (2005). The phenolic compounds of olive oil: structure, biological activity and beneficial effects of human health. Journals of Nutrition Research Reviews, 18: 98-112.

TUIK (2014). http://www.tuik.gov.tr/erișim tarihi. 14.04.2015-29.03.2015

TUIK (2011). http://mww.tuik.gov.tr/erișim tarihi. 29.03.2015

Turan HS, Aydoğdu E, Pekcan T, Colakoğlu H, (2013). Reletionships of olive groves in West Anatolia region of Turkey. Communications in Soil Science and Plant Analysis, Copyright (c) Taylor \& Francis Group, LLC ISSN: 0010-3624 print / 1532 2416 online DOI: 10.1080/00103624.2012.734133, 44: 80-88.
Turan HS, Aydoğdu E, Pekcan T, Çolakoğlu H (2013). Soil and plant relationships olive groves in West Anatolia region of Turkey. Soil, Plant and Food Interactions, 473-481.

Tüzüner A (1990). Toprak ve su analiz laboratuarı el kitabı. Ankara.

Thun R, Hermann R, Knickman E (1955). Die Untersuchung Von BodenNeuman Verlag, Radelbeul und Berlin, pp. 48-48.

Ulgen N, Yutrsever N (1974). Türkiye gübreler ve gübreleme rehberi. Köy İșleri ve Kooperatifleri Bakanlığı. Toprak ve Gübre Araștırma Enstitüsü Teknik Yayınları Serisi. No: 28 Ankara.

UZZK (2014). Hhtp://uzzk.org

Uysal E, Albayrak B, Soyergin S (2011). Gemlik yöresinde yetiștirilen zeytinlerin beslenme durumlarının toprak analizleriyle belirlenmesi. 2. Ulusal Toprak ve Su Kaynakları Kongresi, 22-25 Kasım, s:887-895, Ankara, Türkiye.

Uysal E, Albayrak B, Kayalı F, Karakoç A (2016). Armutlu yöresinde yetiștirilen zeytinliklerde verim ile bazı toprak özellikleri arasındaki ilișkinin belirlenmesi. Nevșehir Bilim ve Teknoloji Dergisi TARGIiD Özel Sayı 19-31 DOI: 10.17100/ nevbiltek.210955

URL:http://dx.doi.org/10.17100/ nevbiltek.210955.

Wolf B (1971). The Determination of boron in soil extracts, plant materials, komposts manures, water and nutrient solutions. Commun. Soil Sci. Plant Anal, 2: 363-374

Zarcinas BA, Cartwrigt B, Spauncer LP 1987. Nitric acid digestion and multielement analysis of plant material by Inductively coupled plasma spectrometry. commun. Soil Sci. Plant Anal., 18:131-147.

Zeytinyağı Sektör Raporu, ISBN: 978-605-9175-57-9. 